\title{
Spatial and temporal length distribution of Zungaro zungaro caught in the Orinoco River Basin of Colombia
}

\section{Distribución espacial y temporal de tallas de captura de Zungaro zungaro en la Orinoquia colombiana}

\author{
Hernando Ramírez-Gil, ${ }^{1}$ Ph.D. \\ ${ }^{1}$ Universidad de los Llanos, Faculty of Basic and Engineering Sciences, Department of Basics, \\ Investigation group: Evaluation, handling and conservation of hydrobiological and fishing resources, $\mathrm{km}$ \\ 12 Vía Puerto López, Vereda Barcelona, Villavicencio, Meta, Colombia. *Correspondence: hramirezgil@ \\ gmail.com
}

Recived: February 2014; Accepted: March 2015.

\begin{abstract}
Objetive. To determine the effect of fishing on capture size of both male and female Zungaro zungaro catfish, historical records of size and spatial distribution of the species were analyzed from the Orinoco Basin in Colombian. Materials and methods. Information was collected by sampling fishing port landings in the region between 1979 and 2011. Each specimen was measured, weighed and sexed. With 5411 records, the average size at capture were compared in time and among the different ports. Size at $50 \%$ maturity was estimated by quinquennium. Results. The average commercial capture sizes of $Z$. zungaro ranged from 35 to $161 \mathrm{~cm}$ standard length, with differences between males and females. From 1979 to 2011, in Puerto Lopez, the size at sexual maturity decreased from 123.8 to $83.4 \mathrm{~cm}$ in females and from 93.3 to 61 in males. In the annual cycle the greater average capture size in females was from April to July and for males from May to June. Average annual length is higher in the higher parts of the Meta and Guaviare river drainages. In the last quinquennium the size at $50 \%$ maturity had fallen $10 \mathrm{~cm}$ in females and $5 \mathrm{~cm}$ in males and it is higher than the average capture size. Conclusions. Populations of $Z$. zungaro in the Colombian Orinoco River Basin have been affected by overfishing and selective fishing of females.
\end{abstract}

Key words: Overfishing, population dynamics, river fisheries, sexual selection (Source: ASFA).

\section{RESUMEN}

Objetivo. Determinar el grado de afección en la población de Zungaro zungaro a partir del análisis del comportamiento histórico y espacial de las tallas de captura de hembras y machos de la especie en la Orinoquia colombiana. Materiales y métodos. La información fue colectada mediante muestreos a los desembarcos en puertos pesqueros de la región entre 1979 y 2011. Cada ejemplar fue medido, pesado y sexado. Con 5411 registros, se estableció la distribución de las tallas medias de captura, que se compararon en el tiempo y entre los diferentes puertos. Se estimó la talla de madurez gonadal (TMG) por quinquenios. Resultados. El rango de las tallas de captura comercial $Z$. zungaro fue de 35 a $161 \mathrm{~cm}$ longitud estándar (LS), con diferencia entre machos y hembras. Entre los años 1979 a 2011, en Puerto López, la talla promedio de captura anual (LS) disminuyó de 123.8 a $83.4 \mathrm{~cm}$ en hembras y de 93.3 a $61 \mathrm{~cm}$ en machos. En el ciclo anual la mayor talla promedio de captura de hembras se presenta en abril a julio y de machos en mayo y junio. La talla promedio de captura anual (TPCA) es superior en las partes altas de los ríos Meta y Guaviare. En el último quinquenio la TMG ha disminuido $10 \mathrm{~cm}$ en las hembras y cinco $\mathrm{cm}$ en los machos y es superior a la TPCA. Conclusiones. Hay afectación sobre la población explotada de $Z$. zungaro por sobrepesca por crecimiento y pesca selectiva de hembras en la Orinoquia colombiana.

Palabras clave: Dinámica de poblaciones, pesca fluvial, selección sexual, sobrepesca, (Source: ASFA). 


\section{INTRODUCTION}

The Zungaro genus belongs to a commercially used group of catfish that reaches large sizes (1), distributed in the basins of the Orinoco (24), Amazonas (5) and Parana Rivers, Paraguay (1). The species is characterized by reproductive migration in one annual spawning period with high relative fertility, free eggs without parental care, and rapid embryogenesis (6). In the Orinoco Z. zungaro $(4,7,8)$, it occupies the second place in size within the group of big catfish with females reaching a standard length of $165 \mathrm{~cm}$ (LS) and males with lengths reported up to $138 \mathrm{~cm}$ LS (2). Size of gonadal maturity was estimated in the upper Rio Meta at $127 \mathrm{~cm}$ LS for females and $107 \mathrm{~cm}$ for males (2). In the Orinoco it has two annual migrations, the first reproductive one in the months of March to June and the second for food from September to December (2). In addition, the intrinsic value of the species, as it holds great social and economic importance in food security for the coastal population of the Arauca, Meta, Guaviare and Orinoco Rivers, and given its high price in the market it is part of a value chain that goes from the fisherman to the major consumer centers.

In 2009 commercial quantities of $Z$. Zungaro in the Colombian Orinoco were in fourth place among the fish species sold in the region, with a contribution of $86 \mathrm{t}$ (2). Annual landings have declined, for example in Puerto Lopez, they went from $50 \mathrm{t}$ in 1985 to $32.3 \mathrm{t}$ in 2009 (2). This decline in landings as well as the large specimens found, the migratory nature of the species and the lack of a conservation program, led it to be included in the Red Book of freshwater fishes of Colombia 2012, in the category of vulnerable (9). This study was done in order to determine if fishery is affecting a population under fishing pressure by analyzing the historical and spatial behavior of catch sizes of males and females of the species.

\section{MATERIALS AND METHODS}

Area of study. The information for this study was collected in the principal landing centers of Z. zungaro in the Colombian Orinoquia.

Río Meta. Puerto López $\left(4^{\circ} 05^{\prime} \mathrm{N}\right.$ and $\left.72^{\circ} 57^{\prime} \mathrm{O}\right)$, Cabuyaro $\left(4^{\circ} 18^{\prime} \mathrm{N}\right.$ and $\left.72^{\circ} 48^{\prime} \mathrm{O}\right)$, Puerto Guadalupe $\left(4^{\circ} 20^{\prime} \mathrm{N}\right.$ and $\left.72^{\circ} 210\right)$, Puerto Gaitán $\left(4^{\circ} 20^{\prime} \mathrm{N}\right.$ and $\left.72^{\circ} 05^{\prime} \mathrm{O}\right)$ and Puerto Carreño $\left(4^{\circ} 11^{\prime} \mathrm{N}\right.$ and $\left.67^{\circ} 28^{\prime} \mathrm{O}\right)$.

Río Guaviare. San José del Guaviare (2034'N and $\left.72^{\circ} 38^{\prime} \mathrm{O}\right)$, Inírida $\left(3^{\circ} 52^{\prime} \mathrm{N}\right.$ and $\left.67^{\circ} 55^{\prime} \mathrm{O}\right)$, as can be seen in figure 1 .

\section{INTRODUCCION}

El género Zungaro pertenece al grupo de siluriformes explotados comercialmente que alcanza grandes tallas (1), se distribuye en las cuencas del Orinoco (2-4), Amazonas (5) y Paraná, Paraguay (1). Sus especies se caracterizan por presentar migración reproductiva en un sólo período de desove al año, alta fecundidad relativa, huevos libres, sin cuidado parental y rápida embriogénesis (6). En la Orinoquia se reporta la especie $Z$. zungaro $(4,7,8)$, que ocupa el segundo lugar en tamaño dentro del grupo de los grandes bagres con hembras que alcanzan tallas de $165 \mathrm{~cm}$ de Longitud estándar (LS) y machos con longitudes hasta $138 \mathrm{~cm} \mathrm{LS} \mathrm{(2).} \mathrm{La} \mathrm{talla} \mathrm{de} \mathrm{madurez}$ gonadal se estimó, en el alto río Meta en $127 \mathrm{~cm}$ LS para hembras y en $107 \mathrm{~cm}$ LS para los machos (2). En la Orinoquia, presenta dos migraciones anuales, la primera en los meses de marzo a junio de tipo reproductivo y la segunda de carácter alimenticio de septiembre a diciembre (2). Además, del valor intrínseco de la especie, su extracción reviste importancia social y económica como aporte a la seguridad alimentaria para la población ribereña de los ríos Arauca, Meta, Guaviare y Orinoco, y dado su alto precio en el mercado como fuente de recursos económicos, en una cadena de valor que va desde el pescador a los grandes centros de consumo.

Las cantidades comercializadas de $Z$. zungaro en la Orinoquia colombiana, ocuparon en el año 2009 el cuarto lugar entre las especies de peces comercializadas en la región, con un aporte de $86 \mathrm{t}$ (2). Sus desembarcos anuales han descendido, por ejemplo en Puerto López, pasaron de 50 t en el año 1985 a 32,3 t en el 2009 (2). Esta disminución en los desembarcos unida al gran tamaño que alcanzan los ejemplares, al carácter migratorio de la especie y a la falta de un programa para su conservación, llevó a que se considerara en el Libro Rojo de peces dulceacuícolas de Colombia 2012, en la categoría de vulnerable (9). El presente trabajo se adelantó con el objetivo de determinar si la pesquería está afectando la población bajo presión de pesca, mediante el análisis del comportamiento histórico y espacial de las tallas de captura de hembras y machos de la especie.

\section{MATERIALES Y MÉTODOS}

Área de estudio. La información para el presente trabajo, fue colectada en los centros de desembarco principales de las pesquerías de $Z$. zungaro en la Orinoquia colombiana.

Río Meta. Puerto López $\left(4^{\circ} 05^{\prime} \mathrm{N}\right.$ y $\left.72^{\circ} 57^{\prime} \mathrm{O}\right)$, Cabuyaro $\left(4^{\circ} 18^{\prime} \mathrm{N}\right.$ y $\left.72^{\circ} 48^{\prime} \mathrm{O}\right)$, Puerto Guadalupe $\left(4^{\circ} 20^{\prime} \mathrm{N}\right.$ y $\left.72^{\circ} 210\right)$, Puerto Gaitán $\left(4^{\circ} 20^{\prime} \mathrm{N}\right.$ y $\left.72^{\circ} 05^{\prime} \mathrm{O}\right)$ y Puerto Carreño $\left(4^{\circ} 11^{\prime} \mathrm{N}\right.$ y $\left.67^{\circ} 28^{\prime} \mathrm{O}\right)$. 


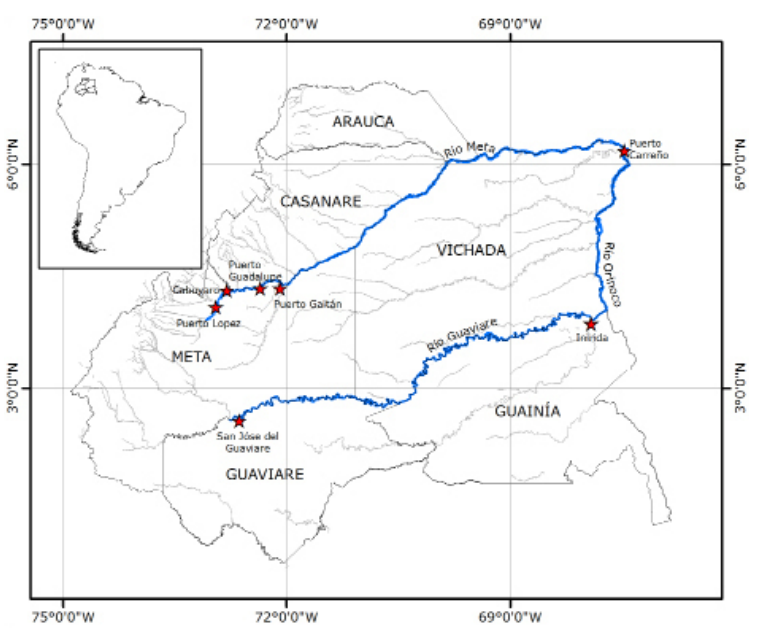

Figure 1. Main landing ports for Zungaro zungaro in the Colombian Orinoco.

Field phase. Information was obtained from samples taken at landings. Each specimen was measured (LS) with a $0.01 \mathrm{~m}$ tape measure, weighed (gutted) with a $100 \mathrm{~kg}$ capacity scale with $0.5 \mathrm{~kg}$ approximation, macroscopically sexed and classified as immature or mature; a male was considered to be mature when pressed gonads released sperm and a female had visible eggs.

Information was taken at different times, with a monthly sampling in Puerto Lopez between 1979 and 1986, Cabuyaro from 1987-1990 and 1992-1995, and Puerto Guadalupe in 1989, 1990, 1993 and 1994, in Puerto Gaitán with two monthly monitoring times from 1999-2001. In the period from 1987-2003, four monthly surveys were done in Puerto Lopez. Data from 2007 to 2011, with daily sampling efforts in Puerto Lopez, Puerto Gaitán, Puerto Carreño, San José del Guaviare and Inírida, belong to the database of the Fisheries and Aquaculture Sector, provided by the management for Fisheries and Aquaculture of the National Institute of Rural Development - INCODER and the National Authority for Aquaculture and Fisheries - AUNAP.

Given the proximity of Puerto Lopez, Cabuyaro, Puerto Guadeloupe and Puerto Gaitán, length data collected in these collection centers were grouped into just one report to facilitate analysis and are herein designated Upper Meta River.

Average capture size. 5411 records were analyzed to find variations in the distribution of average size in time and space. The historical record of the Upper Meta River from 1979 to 2011 was consulted, and in space the average size found in the different collection centers
Río Guaviare. San José del Guaviare (2034'N y $\left.72^{\circ} 38^{\prime} \mathrm{O}\right)$, Inírida $\left(3^{\circ} 52^{\prime} \mathrm{N}\right.$ y $\left.67055^{\prime} \mathrm{O}\right)$, como se puede apreciar en la figura 1.

Fase de campo. La información fue obtenida mediante muestreos realizados a las capturas desembarcadas, cada ejemplar de la especie fue medido (LS) con una cinta métrica de $0.01 \mathrm{~m}$ de aproximación, pesado (eviscerado) con una balanza de $100 \mathrm{~kg}$ de capacidad y $0.5 \mathrm{~kg}$ de aproximación, sexado macroscópicamente y clasificado en inmaduro o maduro, considerando maduro al macho que al presionar la gónada liberaba esperma o a la hembra con huevos visibles.

La frecuencia de toma de información presentó variaciones, con un muestreo mensual en Puerto López entre los años 1979 y 1986, en Cabuyaro en los años 1987 a 1990 y de 1992 a 1995 y en Puerto Guadalupe en los años 1989, 1990, 1993 y 1994. En Puerto Gaitán con dos seguimientos mensuales en los años 1999 al 2001. En el período 1987 a 2003 en Puerto López se hicieron cuatro muestreos mensuales. Los datos de 2007 a 2011, con esfuerzo de muestreo diario en Puerto López, Puerto Gaitán, Puerto Carreño, San José del Guaviare e Inírida, corresponden a la base de datos del Sistema Sectorial Pesquero y Acuícola, suministrada por la Subgerencia de Pesca y Acuicultura del Instituto Nacional de Desarrollo Rural - INCODER y la Autoridad Nacional de Acuicultura y Pesca - AUNAP.

Dada la cercanía entre Puerto López, Cabuyaro, Puerto Guadalupe y Puerto Gaitán los datos de tallas de captura de estos centros de acopio fueron agrupados en uno sólo para facilitar el análisis y se denominó en este documento parte alta del río Meta.

Tallas promedio de captura. A partir de 5411 registros, se analizaron las variaciones en la distribución de las tallas promedio de captura en el tiempo y en el espacio. En el tiempo los registros históricos de la parte alta del río Meta desde el año 1979 hasta 2011 y en el espacio la talla promedio entre los diferentes centros de acopio de la Orinoquia. Para establecer si existían diferencias significativas de tallas entre sexos, entre y dentro de ciclos anuales y espacialmente, se aplicó la prueba de Levene para establecer si había homocedasticidad de varianza, para posteriormente utilizar pruebas paramétricas (Anova y Tukey) o no paramétricas (KruskallWallis y Mann-Whitney) según el caso, utilizando el paquete estadístico SigmaPlot 11(Jandel) con significancia $\alpha=0.05$. 
along the Orinoco was used. To establish whether there were significant differences in size between the sexes as well as between and within yearly cycles and spatially, Levene's test was applied to establish whether there was homoscedasticity variance for later parametric tests (ANOVA and Tukey) or nonparametric (Kruskall Wallis and Mann-Whitney) as appropriate, using the SigmaPlot 11 (Jandel) statistical package with $a=0.05$ significance.

Temporal analysis was based on records obtained in Puerto Lopez (upper Meta River) in 30 years of follow-up work.

Size at maturity. LS data for mature males and females were compared using the Student t statistic test to establish whether there were significant differences between records of both sexes. The size of gonadal maturity was calculated for females $(n=2372)$ and males $(n=1821)$, grouping data by quinquennium. At every quinquennium, 30 class marks were established and for each one an absolute, relative and accumulated frequency was estimated. The relative cumulative frequency was linearized (TFRA) using the equation:

$\operatorname{Tr} r a=L N\left(\frac{1}{f r a}-1\right)$

From the lineal regression between the class mark and this transformation, $a$ and $b$ parameters were estimated in the logistics curve:

$T M G=\left(1+e^{(a-(b+L S))}\right)^{-1}$

Where gonadal maturity (TMG) is considered the size at $50 \%$, measurement that was used to make comparisons between quinquennium.

\section{RESULTS}

Commercial catch sizes of Z. Zungaro in the Colombian Orinoco were within a range of 35 to $161 \mathrm{~cm}$ LS, with significant differences $(p<0.05)$ between males and females. Variations in average catch sizes were evident in both time (within the hydrological and interannual cycle), and space, considering their geographic distribution.

Average capture size. In Puerto López from 1979-2011 the average annual catch size was between $123.8 \pm 7.6 \mathrm{~cm}$ LS in 1991 and $83.4 \pm 29.2 \mathrm{~cm}$ in 2011 for females and between $93.3 \pm 22$ in 1997 and $61 \pm 16 \mathrm{~cm}$ in 2011 in males. In figure 2 a gradual tendency to diminish in size can be observed in the average annual catch sizes of the males in comparison with the
Para los análisis temporales se tomaron como base los registros obtenidos en Puerto López (parte alta del río Meta), de 30 años de seguimiento.

Talla de madurez gonadal. Los datos de LS de machos y hembras maduros se compararon mediante la prueba estadística $t$ de Student, para establecer si había diferencia significativa entre los registros de los dos sexos. La talla de madurez gonadal se calculó para hembras $(n=2372)$ y para machos $(n=1821)$, agrupando los datos por quinquenios. Para cada quinquenio se establecieron 30 marcas de clase y para cada una de ellas se estimaron la frecuencia absoluta, la relativa y la relativa acumulada. La frecuencia relativa acumulada se linealizó (Tfra) mediante la ecuación:

$T f r a=L N\left(\frac{1}{f r a}-1\right)$

A partir de la regresión lineal entre la marca de clase y esta transformación se estimaron los parámetros a y b de la curva logística:

$T M G=\left(1+e^{(a-(b+L S))}\right)^{-1}$

Donde talla de madurez gonadal (TMG) se considera la talla al 50\%, medida que se utilizó para las comparaciones entre quinquenios.

\section{RESULTADOS}

Las tallas de captura comercial de $Z$. zungaro en la Orinoquia colombiana se ajustaron a un rango de 35 a $161 \mathrm{~cm}$ de LS, con diferencia significativa $(p<0.05)$ entre machos y hembras. Se presentó variación en las tallas promedio de captura tanto en el tiempo (dentro del ciclo hidrológico e interanual), como en el espacio considerando su distribución geográfica.

Tallas promedio de captura. En Puerto López, entre los años 1979 a 2011 la talla promedio de captura anual osciló entre $123.8 \pm 7.6 \mathrm{~cm}$ LS en 1991 y $83.4 \pm 29.2 \mathrm{~cm}$ en 2011 en las hembras y entre $93.3 \pm 22$ en 1997 y $61 \pm 16 \mathrm{~cm}$ en 2011 en los machos. En la figura 2, se observa que hay una tendencia gradual hacia la disminución de la diferencia entre las tallas promedio de captura anual de los machos comparadas con las de las hembras; en los primeros 15 años de registros (1979 a 1993), la diferencia promedio de este parámetro entre los dos sexos fue de $35.8 \pm 8.1 \mathrm{~cm}$, que se redujo a $23.4 \pm 7.2 \mathrm{~cm}$ en los siguiente 10 años (1994-2002) y finalmente a $17.7 \pm 4.2 \mathrm{~cm}$, en los últimos siete años (2005-2011). Este comportamiento se generó por la disminución a través del tiempo de la talla promedio de captura anual de las hembras. 
females; in the first 15 years of records (1979 a 1993) the average difference in this parameter between the two sexes was $35.8 \pm 8.1 \mathrm{~cm}$, which decreased to $23.4 \pm 7.2 \mathrm{~cm}$ over the next 10 years (1994-2002) and finally reached $17.7 \pm 4.2 \mathrm{~cm}$ in the last seven years (2005-2011). This behavior was due to a decrease over time of the average annual capture size of females.

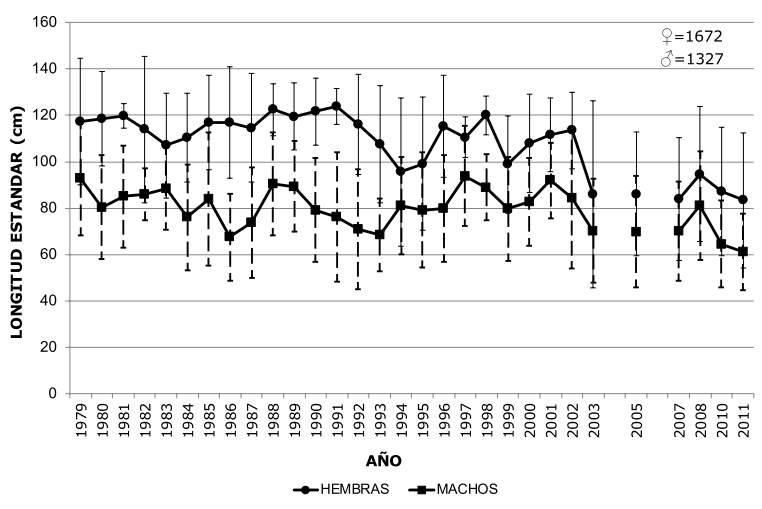

Figure 2. Average sizes ( $\mathrm{LS} \mathrm{cm}$ ) and standard deviation of $Z$. zungaro catches (males and females) in Puerto Lopez. Period 1979-2011.

Within the hydrological cycle, the behavior of the average size of monthly catch (TPCM) in the upper Meta River (Figure 3) was analyzed, and significant differences $(p<0.05)$ were found in the size of females captured April to July (between 113 and $124 \mathrm{~cm}$ LS) with respect to the other months of the year (between 74 and $102 \mathrm{~cm}$ LS). This dynamic was also observed in males for the months of May and June $(p<0.05)$, with significantly higher sizes (between 75 and $109 \mathrm{~cm}$ LS) than in the rest of the annual cycle (between 62 and $73 \mathrm{~cm}$ ). The season with largest sizes coincides with the breeding season of the species in the period of rising waters.

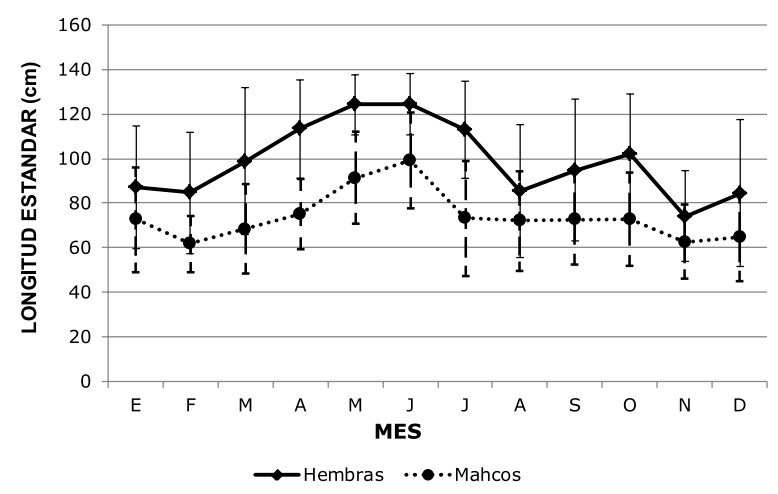

Figure 3. Average size of monthly catch of $Z$. zungaro males and females in the upper Meta River throughout the water cycle (average 19792011).
Dentro del ciclo hidrológico, se analizó el comportamiento de la talla promedio de captura mensual (TPCM) en la parte alta del río Meta (Figura 3), encontrándose que existe diferencia significativa $(p<0.05)$ en la talla de las hembras capturadas en los meses de abril a julio (entre 113 y $124 \mathrm{~cm}$ LS) con respecto a los demás meses del año (entre 74 y $102 \mathrm{~cm}$ de LS). Esta dinámica también se observó en los machos para los meses de mayo y junio $(p<0.05)$, con tallas significativamente más altas (entre 75 y 109 cm LS) que en el resto del ciclo anual (entre 62 y $73 \mathrm{~cm}$ ). La temporada de mayores tamaños coincide con la época reproductiva de la especie en el período de aguas ascendentes.

Para analizar la distribución espacial de tallas entre centros de acopio, se agruparon los registros del total de la población desembarcada en cada puerto en los años 2007 a 2011. Al hacer la comparación entre los dos puertos del río Meta, Puerto López en la parte alta y Puerto Carreño en la parte baja, se encontró que no había diferencia $(p>0.05)$ en la talla promedio de captura mensual (Figura 4 ).

En contraste en el río Guaviare, las tallas de los ejemplares capturados en San José del Guaviare (parte alta) fueron significativamente mayores $(p<0.05)$ a las de los explotados en Inírida (parte baja), como se puede apreciar en la figura 5 . La TPCA de las hembras en San José del Guaviare en el período estudiado fue de $102.9 \pm 26.8 \mathrm{~cm}$ LS y la de los machos de $78.9 \pm 24.6 \mathrm{~cm}$, mientras que en Inírida fue de $59.5 \pm 8.8 \mathrm{~cm}$ en las hembras y $68 \pm 9.1 \mathrm{~cm}$ en los machos.

Talla de madurez gonadal (TMG). La talla de madurez gonadal de las hembras de $Z$. zungaro fue significativamente diferente de la de los machos $(p<0.05)$, por lo anterior se presentan los resultados separados por sexo.

En la parte alta del río Meta, los datos reportados para los 30 años se agruparon y la TMG se estimó por quinquenios, como se presenta en la figura 6 .

Entre 1979 y 1993 la TMG de las hembras permaneció estable por encima de los $119 \mathrm{~cm}$ LS y a partir de ese año descendió diez centímetros hasta ubicarse alrededor de $109 \mathrm{~cm}$ en el período 2006-2011. En los machos la talla de madurez se registraba por encima de $80 \mathrm{~cm} \mathrm{LS}$, pero en el último quinquenio disminuyó a $75 \mathrm{~cm}$, comportamiento que es normal en poblaciones pesqueras sometidas a explotación comercial.

Al comparar los estimativos de TMG de los ejemplares desembarcados en las partes altas de los ríos Meta y Guaviare (Puerto López, último 
To analyze the spatial distribution of sizes between collection centers, total population records landed in each port in the years 2007 to 2011 were grouped together. When comparing the two ports of the Meta River, Puerto Lopez at the top and Puerto Carreño at the bottom, no difference $(p>0.05)$ in average monthly catch size was found (Figure 4).

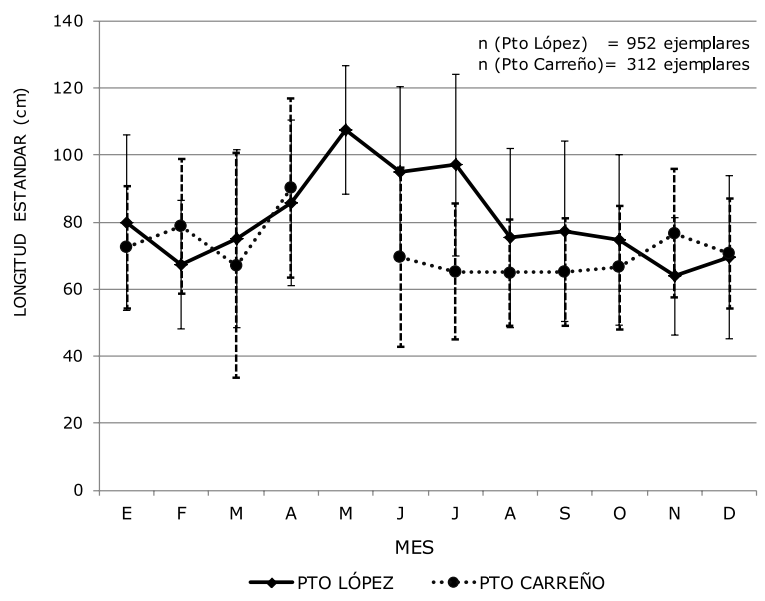

Figure 4. Comparison of average monthly catch sizes in Puerto Lopez and Puerto Carreño (2007, $2008,2010,2011)$. In May there are no records in Puerto Carreño due to the closure period.

In contrast with the Guaviare River, sizes of fish caught in San José del Guaviare (upper part) were significantly higher $(p<0.05)$ than those in Inírida (lower part), as seen in figure 5. The TPCA of females in San José del Guaviare during the period studied was $102.9 \pm 26.8 \mathrm{~cm}$ LS and that of males $78.9 \pm 24.6 \mathrm{~cm}$, while in Inírida it was $59.5 \pm 8.8 \mathrm{~cm}$ in females and $68 \pm 9.1 \mathrm{~cm}$ in males.

Size at gonadal maturity (TMG). The size at gonadal maturity for $Z$. Zungaro females was significantly different from that of males $(p<0.05)$, so that the results are reported by sex.

In the Upper Meta River the reported data over 30 years was grouped and the TMG was estimated in quinquennium, as shown in figure 6 .

From 1979-1993 the TMG of females remained stable and above $119 \mathrm{~cm} \mathrm{LS}$, and from that year dropped ten centimeters to settle around 109 $\mathrm{cm}$ in 2006-2011. In males the size at maturity was recorded at over $80 \mathrm{~cm}$ LS, but in the last five years decreased to $75 \mathrm{~cm}$, which is normal behavior in commercially exploited fish stocks. quinquenio, y San José del Guaviare), se observó que en la población del río Meta esta medida fue menor en hembras ( $108.8 \mathrm{~cm}$ LS) y en machos $(74.9 \mathrm{~cm})$, que en el grupo del río Guaviare donde la TMG de las hembras fué de $113.6 \mathrm{~cm}$ LS y la de los machos de $88.3 \mathrm{~cm}$ (Figura 7).

En el período estudiado la talla promedio de captura anual de las hembras ha sido inferior a la TMG a través del tiempo (Figura 8) acentuándose la diferencia en el último quinquenio. En los machos en el primer quinquenio analizado la TPCA fue superior a la TMG y en los quinquenios siguientes la dinámica se invirtió; sin embargo, el valor de estos dos parámetros ha sido muy cercano.

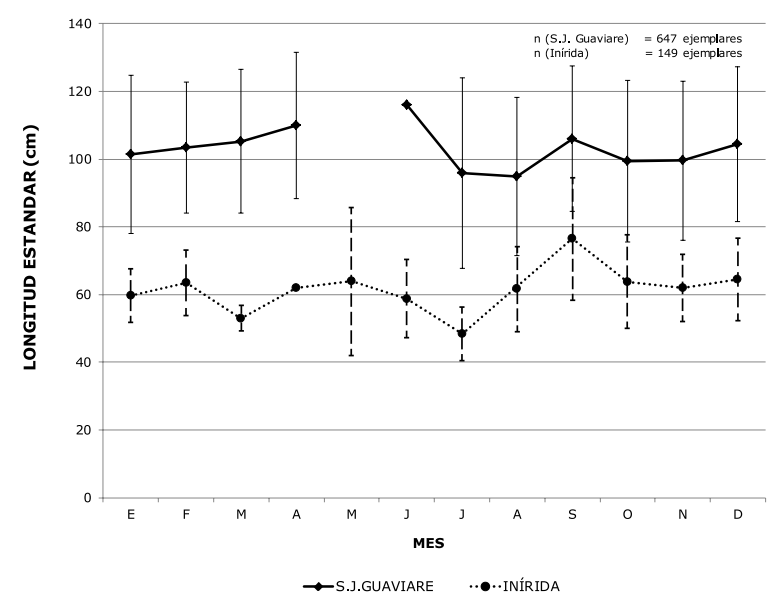

Figure 5. Monthly comparison of average catch sizes marketed in the upper Guaviare River (San Jose) and the lower area (Inírida). Period: 2007, 2008, 2010, 2011.

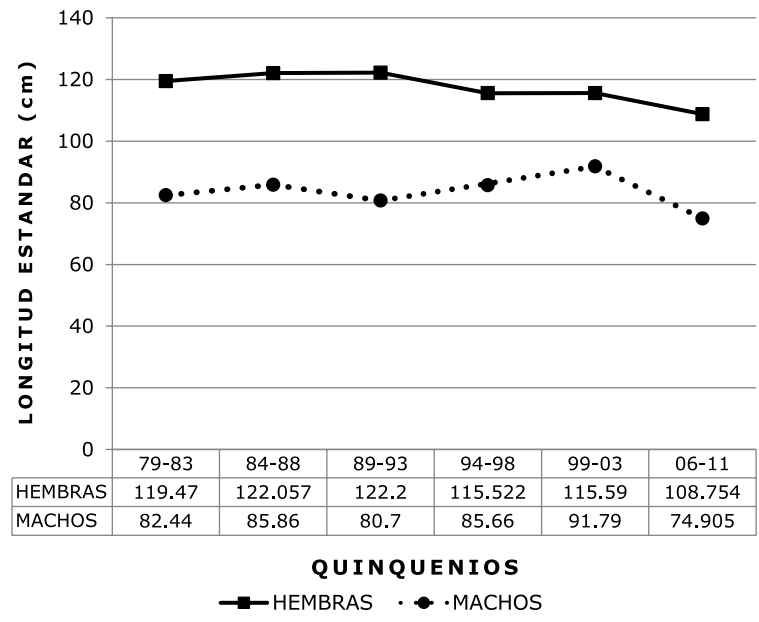

Figure 6. Historical variation for five year periods ( 30 years) of the sizes at gonadal maturity of $Z$. zungaro males and females in the upper Meta River. 
Comparing the estimates of TMG of fish landed in the upper parts of the Meta and Guaviare Rivers (Puerto Lopez, last quinquennium, and San José del Guaviare), we observed that in the Meta River this measurement was lower in females (108.8 $\mathrm{cm} \mathrm{LS})$ and males $(74.9 \mathrm{~cm})$ than in the group in the Guaviare River where the TMG of females was $113.6 \mathrm{~cm}$ LS and that of males was 88.3 cm (Figure 7).

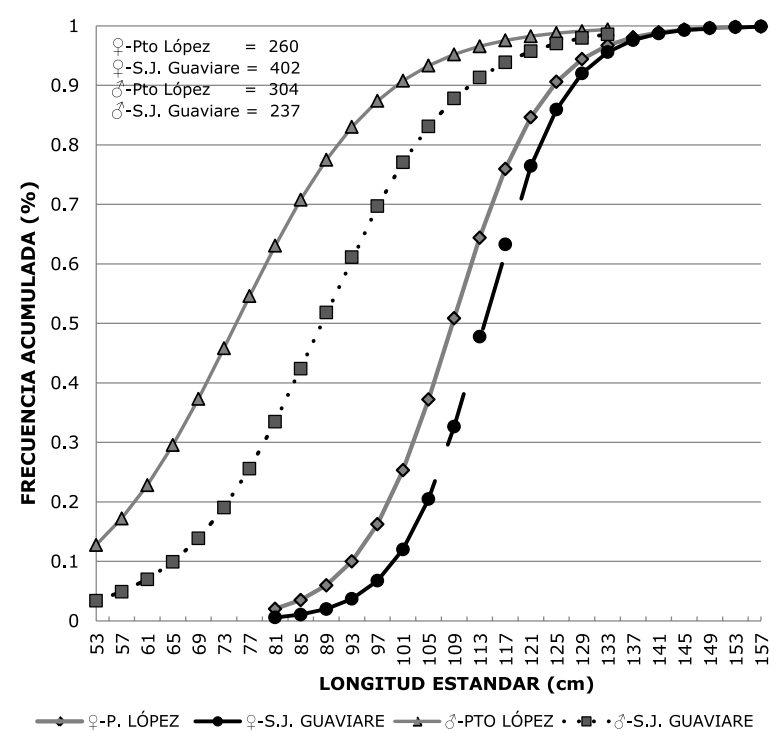

Figure 7. Spatial variation of length at gonadal maturity (TMG) of $Z$. zungaro males and females between the upper parts of the Meta and Guaviare (2007-2011) rivers.

In the period studied, the average annual catch size of females has been below the TMG over time (Figure 8), accentuating the difference in the last five years. In males in the first five years the TPCA analyzed was superior to TMG and in the following quinquenniums the dynamics were reversed; however, the value of these two parameters was very close.

At the head of the Guaviare River the TPCA of females $(102.9 \pm 26.8 \mathrm{~cm}$ LS $)$ is less than the TMG (108.8 cm LS), in males the TPCA (78.9 \pm $24.6 \mathrm{~cm} \mathrm{LS})$ is lower than TMG $(88.3 \mathrm{~cm})$.

\section{DISCUSSION}

Average catch sizes. The difference between the size of females and males found in this study is consistent with the report of sexual dimorphism indicating higher growth rates in females than in males (2). Females reach sizes of up to 165 $\mathrm{cm}$ LS and males $138 \mathrm{~cm}$ (2), higher than those
Para la parte alta del río Guaviare la TPCA de las hembras (102.9 $\pm 26.8 \mathrm{~cm}$ LS) es inferior a la TMG (108.8 cm LS), similar en los machos la TPCA (78.9 $\pm 24.6 \mathrm{~cm}$ LS) es menor a la TMG $(88.3 \mathrm{~cm})$.

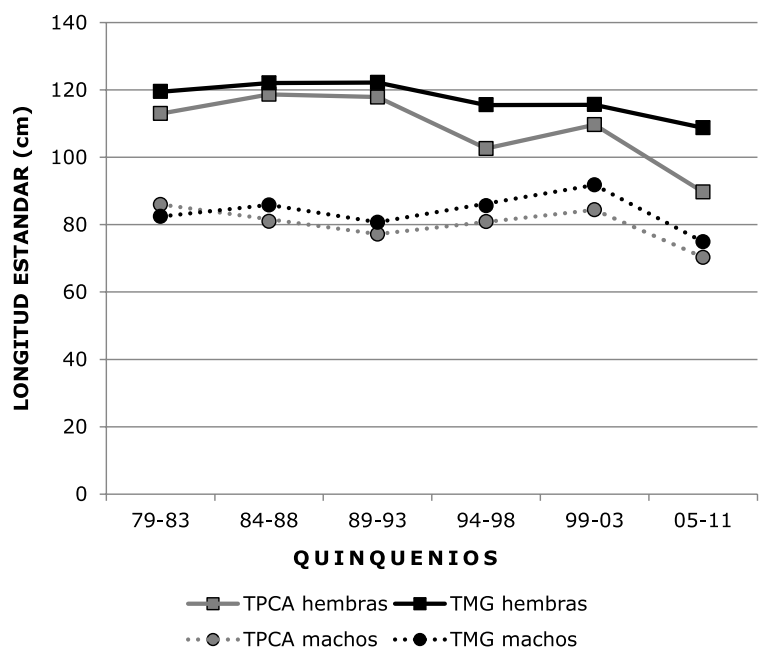

Figure 8. Comparison of size at gonadal maturity and average catch size at five-year periods in the upper Meta River.

\section{DISCUSIÓN}

Tallas promedio de captura. La diferencia entre las tallas de las hembras y los machos encontrada en este estudio, concuerda con el reporte de dimorfismo sexual que indica mayor tasa de crecimiento en las hembras que en los machos (2); las hembras alcanzan tallas hasta de $165 \mathrm{~cm}$ LS y los machos de $138 \mathrm{~cm}$ (2), superiores a la reportadas para $Z$. jahu del rio Cuaiba (cuenca del río Paraguay) de 163 $\mathrm{cm}$ longitud furcal (10). De acuerdo con los resultados históricos encontrados en el presente trabajo se observa disminución progresiva en las tallas medias de captura de las hembras y los machos, con una caída abrupta entre los años 2005 a 2011, como consecuencia del efecto inevitable de las pesquerías que remueven los ejemplares de las clases más grandes o más viejos de la población (11-13).

Cuando hay diferencia en la talla de los dos sexos, los ejemplares del sexo de mayor tamaño son más vulnerables a la presión de pesca y la disminución en la talla de este sexo es más notoria (11), lo que se evidenció claramente en el caso de $Z$. zungaro en el alto Meta, donde la selección de los artes de pesca dirigida hacia las hembras se reflejó en la reducción de las tallas 
reported for river $Z$. jahu in the Cuaibá River (Paraguay River Basin) of $163 \mathrm{~cm}$ in length (10). According to historical results found in this study, a progressive decrease is observed in the average size of captured females and males, with a sharp drop from 2005 to 2011 as a result of the inevitable effect that fisheries have when they remove larger or older fish from the population (11-13).

When there is a difference in size between the two sexes, larger fish are more vulnerable to fishing pressure and a decrease in the size of that sex is more noticeable (11), which was clearly evident in the case $Z$. zungaro in the upper Meta, where fishing selectivity directed towards females was reflected in the reduction of the average size of catch, greater in females.

Also variations were observed in the average monthly catch size. Larger sizes were found in the months corresponding to the reproductive period of the species, April to June (2), when the nets select especially females due to increased circular perimeter because of enlarged gonads, increasing mortality for this population group, as has been described for other fisheries (14).

Fisheries exploit the population according to their size frequency distribution (15), and larger sizes of $Z$. zungaro were reported in the upper parts of rivers where adults and minors are concentrated and in the lower parts where juveniles are found. Reproductive migration of adults has been seen towards the headwaters of the Arauca, Meta and Guaviare (2) rivers, but not of juveniles that, it is assumed, gradually head upriver but not in bulk. This move upstream of juveniles with sizes above $35 \mathrm{~cm}$ would primarily be related to migration of bocachico, Prochilodus mariae, their main food and other prey that are not as abundant as Mylossoma duriventre, Leporinus sp., Astyanax spp. and Triportheus ssp. (during the period of falling and low water), when they leave the lagoons and flooded areas to go upriver.

$Z$. Zungaro is thought to make short migrations that could be similar to $Z$. jau, in which a linear path of $31.4 \mathrm{~km}$ was estimated over a year (16), since they are usually found in the main channel of rivers and whitewater pipes, in deep depressions below wooded sections or waterfalls $(2,16)$, where they wait for their food to pass by, without having to chasse prey, hence the morphological appearance of robust structure and an almost square head, which differs in body frame when compared with other large migratory catfish of the same group. medias de captura, de mayor magnitud en las hembras.

Igualmente se observaron variaciones en las tallas promedio de captura mensuales. Los mayores tamaños se presentaron en los meses que corresponden al período reproductivo de la especie, abril a junio (2), cuando las redes seleccionan en especial a las hembras por el incremento en su perímetro circular debido a sus gónadas, lo que incrementa la mortalidad por pesca para este grupo de la población, tal como ha sido descrito para otras pesquerías (14).

La pesquería explota ejemplares de la población de acuerdo con su distribución de frecuencia de tallas (15), así las mayores tallas de ejemplares de $Z$. zungaro, se reportaron en las partes altas de los ríos donde se concentran los adultos y las menores en las partes bajas donde se encuentran los juveniles. Se ha observado migración reproductiva de adultos de la especie a las cabeceras de los ríos Arauca, Meta y Guaviare (2), pero no de juveniles los que se asume ascienden paulatinamente cauce arriba, pero no de forma masiva. Ese desplazamiento aguas arriba de juveniles con tallas superiores a los $35 \mathrm{~cm}$, estaría principalmente relacionado con la migración del bocachico, Prochilodus mariae, su principal alimento y de otras presas que lo acompañan en menor abundancia como Mylossoma duriventre, Leporinus sp., Astyanax spp. y Triportheus ssp. (durante el período de aguas descendentes y aguas bajas), cuando estas abandonan las lagunas y áreas inundadas para remontar el río.

Se considera que $Z$. zungaro realiza migraciones cortas que podrían ser similares a las de $Z$. jau especie para la cual se estimó un recorrido lineal de $31.4 \mathrm{~km}$ a lo largo de un año (16) ya que generalmente se encuentra en el cauce principal de ríos y caños de aguas blancas, refugiado en depresiones profundas debajo de palizadas o en chorros de raudales $(2,16)$, donde se dedica a esperar que pase su alimento, sin perseguir demasiado las presas, de allí la apariencia morfológica de la especie de estructura robusta y cabeza casi cuadrangular, la cual difiere en contextura corporal cuando se le compara con los otros grandes bagres migratorios del grupo de los Siluriformes.

Talla de madurez gonadal. La TMG de las hembras ha disminuido desde el quinquenio 19941998, situación que se acentúo entre 2006-2011; en los machos la TMG ha sido superior a $80 \mathrm{~cm}$ de LS, sin embargo en el último quinquenio (20062011) bajo significativamente, comportamiento que sugiere que por efecto de la actividad pesquera, 
Size of gonadal maturity. The TMG of females has declined since 1994-1998, a situation that increased from 2006-2011; TMG in males was higher than $80 \mathrm{~cm}$ LS, but in the last five years (2006-2011) it decreased significantly, suggesting that the effects of fishing, larger and older individuals are declining in population, resulting in early maturity of fish at smaller sizes, as has been reported in other fisheries $(10,11,13,17,18,19)$. This can also affect the reproductive period, as this tends to be wider seasonal and spatially with parental at older ages when compared to younger (13).

The decrease in TMG adversely affects the rate of population growth by eliminating fish that have high reproductive value $(11,19)$, since size is affected by maternal size, as has been amply demonstrated, since longer and older females produce larger and stronger eggs and larvae, with a greater chance of survival than those of younger females $(11,13,20)$. Reproduction at younger ages and smaller sizes reduces fertility (20), resilience to environmental change (17, 19), and increases the sensitivity of larvae to climate variations, which increases sensitivity of recruitment to changes due to climate (13).

Spatial results also indicate that females and males of the upper Guaviare River maintain a TMG greater than those recorded in the upper Meta River. Fishery in the upper Guaviare River is relatively recent, since geographical isolation and public order problems have limited its development, in contrast to the more than 50 years of fishing tradition in the upper Meta River. Even so, the TMG of females in upper Guaviare River is less than what the historical records indicate in the upper Meta River in 2006-2011, showing that as in Meta, in that area high pressure is being exerted on fish specimens of larger size, the females.

It is clear that historically and spatially the TPCA of females was lower than the TMG, which means that fishing pressure has been exerted on specimens that did not reach TMG, which is considered the optimum catch length, which suggests that overfishing relative to growth exists. Additionally, the TPCA is below the 10th percentile of the maturity curve in Puerto López and in the 30th percentile in San José del Guaviare, which may result in the low numbers of this sex that can reproduce at least once before they are caught, jeopardizing the stability of the species in the basins of the Meta and Guaviare rivers.

In conclusion, the negative impact of fisheries on the species was noted, which may affect future los individuos de mayor tamaño y edad están disminuyendo en la población, favoreciendo la maduración temprana de los ejemplares a menores tallas, como se ha reportado en otras pesquerías $(10,11,13,17,18,19)$. Lo anterior también puede afectar el período reproductivo, ya que este tiende a ser más amplio estacional y espacialmente con parentales de mayor edad al compararlos con los más jóvenes (13).

La disminución en la TMG afecta negativamente la tasa de crecimiento poblacional, por la eliminación de los ejemplares de alto valor reproductivo $(11,19)$ ya que se ha demostrado ampliamente el efecto maternal dependiente del tamaño, en el que las hembras de mayor longitud y edad producen huevos y larvas más grandes y fuertes, con mayores probabilidades de sobrevivencia que los de hembras más jóvenes $(11,13,20)$; la reproducción a edades más tempranas y menores tamaños reduce la fecundidad (20), la resiliencia a cambios ambientales $(17,19)$ y aumenta la sensibilidad de las larvas a variaciones climáticas, lo que incrementa la sensibilidad del reclutamiento a cambios interanuales por el clima (13).

Espacialmente también los resultados indican que las hembras y machos de la parte alta del río Guaviare mantienen una TMG mayor que los registrados en la parte alta del río Meta. La pesquería en el alto río Guaviare es relativamente reciente, ya que el aislamiento geográfico y los problemas de orden público han limitado su desarrollo, en contraste con la tradición pesquera de más de 50 años en el alto río Meta. Aun así la TMG de las hembras en el alto río Guaviare es inferior a los registros históricos del alto río Meta anteriores al quinquenio 2006-2011, demostrando que como en el Meta, en esa zona también se está ejerciendo alta presión pesquera sobre los ejemplares de mayor talla, las hembras.

Es claro que histórica y espacialmente la TPCA de las hembras ha sido inferior a la TMG, lo que implica que la presión de pesca se ha ejercido sobre ejemplares que no alcanzaron la TMG, que se estimaría la longitud óptima de captura, lo que hace pensar que hay sobrepesca relativa al crecimiento. A esto se suma que la TPCA se encuentra por debajo del percentil 10 de la curva de madurez en Puerto López y en el percentil 30 en San José del Guaviare, lo que puede estar conduciendo a que un bajo número de ejemplares de este sexo llegue a reproducirse al menos una vez antes de ser capturados, poniendo en riesgo la estabilidad de la especie en las cuencas de los ríos Meta y Guaviare.

En conclusión se evidenció el impacto negativo de la pesquería sobre la especie que podría afectar en el futuro la productividad debido a disminuciones 
productivity due to declines in recruitment and in the rate of population growth, given that overfishing and selective fishing of adult females is a practice. Extending the closure period of three months starting in April is recommended to facilitate migration and increase parental reproductive success of the species in the area. The significant difference in size between males and females in the TMG $Z$. zungaro, as well as the dynamic variation of this parameter in the population over time, demonstrates the urgent need to directly monitor and record catches and individualized long-term analysis by gender that will help detect and establish measures to ensure a sustainable exploitation of this resource. en el reclutamiento y en la tasa de crecimiento poblacional, dada la sobrepesca por crecimiento y la pesca selectiva de hembras adultas. Se recomienda ampliar el periodo de veda a tres meses iniciando en el mes de abril, a fin de facilitar la migración de los parentales y aumentar el éxito reproductivo de la especie en la zona. La diferencia significativa de tallas entre machos y hembras en la TMG de $Z$. zungaro, como también la variación dinámica de este parámetro en la población a lo largo del tiempo, demuestra la imperante necesidad de estar haciendo un seguimiento directo a las capturas y un registro y análisis individualizado a largo plazo por sexo que permitan detectar y establecer a tiempo medidas para garantizar la explotación sustentable de este recurso.

\section{REFERENCES}

1. Boni TA, Padial AA, Prioli SMAP, Lucio LC, Maniglia TC, Bignotto TS et al. Molecular differentiation of species of the genus Zungaro (Siluriformes, Pimelodidae) from the Amazon and Paraná-Paraguay River basins in Brazil. Genet Mol Res 2011; 10(4):2795-2805.

2. Lasso CA, Agudelo-Córdoba E, JiménezSegura LF, Ramírez-Gil H, MoralesBetancourt M, Ajiaco-Martínez, et al (Editores.) I. Catálogo de los Recursos Pesqueros continentales de Colombia. Serie Editorial Recursos Hidrobiológicos y Pesqueros continentales de Colombia. Bogotá, D.C., Colombia: Instituto de Investigación de Recursos Biológicos Alexander von Humboldt (IAvH). 2011; 537-541.

3. Machado-Allison A, Bottini B. Especies de la pesquería continental venezolana: un recurso natural en peligro. Bol Acad C Fís Mat y Nat 2010; 70(1):59-75.

4. Pérez-Lozano A, Barbarino A. Parámetros poblacionales de los principales recursos pesqueros de la cuenca del río Apure, Venezuela (2000-2003). Lat Am J Aquat Res 2013; 41(3):447-458.

5. Agostinho AA, Pelicice FM, Gomes LC. Dams and the fish fauna of the Neotropical region: impacts and management related to diversity and fisheries. Braz J Biol 2008; 68(4):1119-1132
6. Godinho AL, Reis I, Godinho H. Reproductive ecology of Brazilian freshwater fishes. Environ Biol Fish 2010; 87:143-162

7. Maldonado-Ocampo JA, Vari RP, Usma JS. Checklist of the freshwater fishes of Colombia. Biota Colombiana 2008; $9(2): 143-237$.

8. Lasso C, Usma JS, Villa F, Sierra-Quintero MT, Ortega-Lara A, Mesa LM, et al. Peces de la Estrella Fluvial Inírida: ríos Guaviare, Inírida, Atabapo y Orinoco, Orinoquía colombiana. Biota Colombiana 2009; 10(12):89-122.

9. Mojica JI, Usma JS, Alvarez-León R, Lasso CA (Editores). Libro rojo de peces dulceacuícolas de Colombia. Bogotá, D. C., Colombia: Instituto de Investigación de Recursos Biológicos Alexander von Humboldt, Instituto de Ciencias Naturales de la Universidad Nacional de Colombia, WWF Colombia, Universidad de Manizales. 2012; 192-195.

10. Mateus LAF, Penha JMF. Dinâmica populacional de quatro espécies de grandes bagres na bacia do rio Cuiabá, Pantanal norte, Brasil (Siluriformes, Pimelodidae). Rev Bras Zool 2007; 24(1):87-98.

11. Fenberg P, Roy K. Ecological and evolutionary consequences of size-selective harvesting: how much do we know? Mol Ecol 2008; 17:209-220 
12. Longhurst $A$. The sustainability myth. Fish Res 2006; 81:107-112

13. Perry RI, Cury $P$, Brander $K$, Jennings $S$, Möllmann C, Planque B. Sensitivity of marine systems to climate and fishing: Concepts, issues and management responses. J Mar Syst 2010; 79(3):427-435.

14. Rijnsdorp AD, Grift RE, Kraak SBM. Fisheries-induced adaptive change in reproductive investment in North Sea plaice (Pleuronectes platessa)? Can J Fish Aquat Sci 2005; 62(4):833-843.

15. Enberg K, Jørgensen C, Dunlop E, Varpe O, Boukal D, Baulier $L$ et al. Fishing-induced evolution of growth: concepts, mechanisms and the empirical evidence. Mar Ecol 2012; $33: 1-25$.

16. Alves CBM, Silva LGM, Godinho AL. Radiotelemetry of a female jaú, Zungaro jahu (Ihering, 1898) (Siluriformes: Pimelodidae), passed upstream of Funil Dam, rio Grande, Brazil. Neotrop Ichthyol 2007; 5:229-232.
17. Jørgensen $C$, Enberg $K$, Dunlop ES, Arlinghaus R, Boukal DS, Brander K, et al. Ecology-Managing evolving fish stocks. Science 2007; 318(5854):1247-1248.

18. Heino M, Baulier L, Boukal DS, Ernande B, Johnston FD, Mollet FM et al. Can fisheriesinduced evolution shift reference points for fisheries management? ICES J Mar Sci 2013; 70:707-721.

16. Laugen AT, Engelhard GH, Whitlock R, Arlinghaus R, Dankel DJ, Dunlop ES et al. Evolutionary impact assessment: accounting for evolutionary consequences of fishing in an ecosystem approach to fisheries management. Fish Fish 2014; $15: 65-96$

17. Venturelli PA, Shuter BJ, Murphy CA. Evidence for harvest-induced maternal influences on the reproductive rates of fish populations. Proc Biol Sci 2009; 276(1658):919-924 